Volume 9

Issue 2 Time, Movement, and Space: Genocide

Studies and Indigenous Peoples

Article 11

$10-2015$

\title{
Liberating Genocide: An Activist Concept and Historical Understanding
}

Tony Barta

La Trobe University

Follow this and additional works at: https://digitalcommons.usf.edu/gsp

\section{Recommended Citation}

Barta, Tony (2015) "Liberating Genocide: An Activist Concept and Historical Understanding," Genocide Studies and Prevention: An International Journal: Vol. 9: Iss. 2: 103-119.

DOI:

http://dx.doi.org/10.5038/1911-9933.9.2.1335

Available at: https://digitalcommons.usf.edu/gsp/vol9/iss2/11

This Conference Proceeding is brought to you for free and open access by the Open Access Journals at Digital Commons @ University of South Florida. It has been accepted for inclusion in Genocide Studies and Prevention: An International Journal by an authorized editor of Digital Commons @ University of South Florida. For more information, please contact digitalcommons@usf.edu. 


\section{Liberating Genocide: An Activist Concept and Historical Understanding}

\section{Acknowledgements}

This article originated as a keynote address at the 2014 Conference of the International Association of Genocide Scholars at the University of Manitoba. I am indebted to the organizers and the participants, and to continuing discussion with colleagues. 


\title{
Liberating Genocide: An Activist Concept and Historical Understanding
}

\author{
Tony Barta \\ La Trobe University \\ Melbourne, Victoria, Australia
}

\begin{abstract}
From the outset, historians of genocide have seen themselves as activists. Among historians of colonial societies that is what distinguishes them most in relation to indigenous peoples. An ethnographic sensibility should be visible in any such study, and the more so when a question of genocide is raised. After all, if we do not have a sense of difference between peoples we fail the test of genocide at the first hurdle. And if we do not have an ethnographic sensibility towards our own cultures (including academic cultures) we will fail to make the most of our role in affecting deeply ingrained kinds of historical consciousness. Examples from Australia make this painfully plain. Is there any chance of opening a bridge between the completely different worlds of those who profited from genocide and those who suffered for it? How can that cause be advanced inside and outside the academy? We are thriving as a sub-discipline, but where to from here? Liberating genocide into a wider discourse may be the way to connect the adventure of ethnographic history, the conceptual illumination of episodes, to the vast field of global relations the understanding of colonialism requires.
\end{abstract}

Keywords: genocide, history, colonialism, Australia, consciousness, Lemkin

My first attempt at liberating genocide was a disaster. It was at the Hakoah Jewish Sports Club in Sydney, with a very large audience of elderly people. The year was 1985, and I thought it was time, but it was certainly not the place. I had written a paper, After Auschwitz: Consciousness of Genocide in Australia for a conference On Being a German-Jewish Refugee in Australia. ${ }^{1}$ Martin Broszat, speaking about Nazi Germany, was politely received. My remarks on Australia did not go down so well. Konrad Kwiet, behind me, said: "Mention your mother, mention your mother." My parents were both in the front row. It didn't help. When I said the place where we now were was not acquired without killing, old people advanced down the aisles displaying the Auschwitz numbers on their arms. I was pulled from the lectern by a young Zionist who is now a very important lawyer.

Liberating genocide from the Holocaust remains problematic and even today I have to stake out that my purpose then, and ever since, has not been to diminish the tragedy of the Holocaust as genocide by even a hair's breadth. I celebrate every advance in our understanding-most recently Claude Lanzmann's reworking of his interviews with Benjamin Murmelstein in The Last of the Unjust. My concern about consciousness of genocide in Australia, however, has not diminished. Here progress has been so painful-no, let me put that the other way round: so painless for Australians - that my sense of failure is much magnified over my initial indignity. What especially troubles me is that this lack of impact has persisted through the most extraordinary flourishing of genocide scholarship. My Australian colleagues with international reputations are legion; the global movement of scholarly awareness that simply wasn't here thirty years ago is in large part a tribute to them.

Let me make clear how I do not want to liberate genocide. I do not want to liberate it from Raphael Lemkin or his original definitions about violence done to human groups identified by ethnicity or nation. The horrors of Rwanda and Sudan and Iraq demand his clear vision and purpose. I remain uneasy (as representatives of oppressive regimes were in 1946) about its extension to political groups, or to mass murder within the same ethnicity. It is too late to take back the Cambodian genocide perpetrated by some Cambodians against others and indeed the counter-argument has been made: should not genocide be extended to all attempts at annihilating difference? ${ }^{2}$ Yes, we should look again at the Atlantic slave trade, where African lives and African peoples counted for nothing. No, not all mass deaths are genocides and not all genocides involve a dramatic episode of mass death. My long quest to liberate genocide has had a consistent purpose: to free Lemkin's concept from the accretions wilfully or ignorantly imposed on it, and to demonstrate-first of all in 
Australia - how we can restore its meaning and its utility.

Both Lemkin's original criteria and those he installed in the Genocide Convention should have created no problems of definition in writing about Australia's past. Indeed, Australians have readily accepted that a genocide took place in Tasmania. That's it, though, and was a long time ago. ${ }^{3}$ To quarantine an unfortunate past there, ignoring the larger genocidal process in the nation's founding, is not just a populist or uneducated project. My profession, with a small number of exceptions, the usual suspects, has seized the temper of the times to declare itself liberated from genocide as well. The most recent evidence is in the two volumes of a new Cambridge History of Australia, written by some seventy Australian historians. Some of them, notably Ann Curthoys and Anna Haebich, have themselves been key contributors to genocide awareness in Australia. The senior editor made his reputation as a doyen of the academic Left. There is not one mention of genocide. There are two chapters, one in each volume, on Settler-Indigenous relations. Genocide does not appear.

It is not just my personal failure; what of all the powerful work by Dirk Moses, Ann Curthoys, John Docker, Norbert Finzsch, Colin Tatz and Patrick Wolfe? Where has it gone? What of the earlier interventions by Bernard Smith, Charles Rowley and Raymond Evans? It is half a lifetime since I got into trouble in Sydney, since Colin Tatz asked if my remarks might not be too surreal for general consumption. Most of my profession has remained not only deaf to our interventions but tone deaf to the international discourse in journals, conferences and memorial institutions. ${ }^{4}$

What is the role of scholarship, with its non-indigenous origins and weighting, in this historical moment? In trying to tease out whether the thirty-year effort to import the concept of genocide into Australian history has kept pace with the changes in which indigenous people live their lives, I have had to ask whether this import can free itself from the colonialism that brought genocide to indigenous peoples around the globe. Might we proceed from Decolonizing Museums and Decolonizing Methodologies to decolonizing genocide? That does not strike me as appropriate or even possible-Lemkin, starting from Nazi Rule in Poland, linked genocide to colonialism from the outset-but decolonization movements were more positively called liberation movements and there are definite advances in liberating genocide from the Eurocentric constraints of its origins even to the point of liberation from genocide as well. ${ }^{5}$

To keep genocide effective as a concept we have to engage with four realities of Lemkin's word:

- its birth in activism;

- the tensions between its legal and historical deployment;

- its capacity to block rather than enhance understanding;

- the burden of historical accretions that weigh against it in both activism and interpretation.

My continuing ambition to make genocide a concept that does not close off engagement, especially in societies based on colonialism, is brought up against these realities at every outing. Outside the academic realm of Genocide Studies the word brings down a boom gate, end of story. Genocide? Come on. This was not like Nazi Germany. Historians of genocide, I argue, have no choice but to meet these challenges. We must:

- separate genocide from the Holocaust, where some activists still try to keep it;

- work around the word where it acts as a block;

- keep insisting that historical understanding has very different requirements from prosecuting genocide as a crime;

- further promote the need to read intention in actions, not only in words;

- make historical work its own kind of activism, creating changes of consciousness about the past for the present-and the future.

Clearly, this takes me into the realm of what has been called critical genocide studies. In a recent issue of Genocide Studies and Prevention some important questions were addressed and some further questions asked to be addressed ${ }^{6}$ For me the big one is the role of history as a discipline and 
its relation to other fields recognized as having special contributions to make in genocide studies, most importantly sociology and anthropology. Ethnographic history embraces theory and in my own case became part of a larger intellectual project that influenced my encounter with Bavaria and Nazism, and then with European settlement and settled Aboriginal peoples. ${ }^{7}$ The dialectics between closely examined case studies and larger conceptions of historical process were to be explicated rather than assumed, and the widest range of insights might potentially be deployed. This is of prime importance in the understanding of societies where internal pressures allied with interests and ideologies to produce genocidal outcomes. In the case of Nazi Germany we have become used to locating perpetrators and their psychology in the economics, politics, social structures and cultures of their time. In colonizing societies there remains much work to be done. My purpose here is to advance the activism of genocide scholars in colonial studies and to examine how liberation from all the accretions around genocide might advance historical understanding of what took place.

From the outset, historians of genocide have seen themselves as activists. Among historians of colonial societies that is perhaps what distinguishes them most, notably and quite fundamentally in relation to indigenous peoples. An ethnographic sensibility should be visible in any such study - it isn't always - and the more so when a question of genocide is raised. After all, if we do not have a sense of difference between peoples we fail the test of genocide at the first hurdle. And if we do not have an ethnographic sensibility towards our own cultures (including academic cultures) we will fail to make the most of our role in affecting deeply ingrained kinds of historical consciousness. Is there any chance of opening a bridge between the completely different worlds of those who profited from genocide and those who suffered for it? How can that cause be advanced inside and outside the academy? We are thriving as a sub-discipline, but where to from here? How can we reach the minds of colleagues in wider academic circles? Can we better engage with those within our disciplines who reject genocide and at the same time open up perspectives on genocide across disciplines? Might my now venerable conception of relations of genocide help construct the kind of bridge that academics outside our specialty can venture on to as we connect more adventurously with their disciplines? Could it expand the connecting adventure of ethnographic history, the conceptual illumination of episodes, into the vast field of global relations colonialism requires?

In my own discipline I continue to hope that there are kinds of history that can be intriguing, inclusive and publicly effective. How can we reach beyond the academy? Can historians help make genocide history?

\section{Ethnographic History and Genocide}

An intellectual journey replete with failure has not diminished my hope that genocide can be liberated from popular misconceptions into a more effective role in historical understanding. I have a rather firm idea of how we need to do this, by extending our reach into all the humanities and especially into the kind of enterprise celebrated in the brief but influential school of ethnographic history that surrounded me in my own department. ${ }^{8}$ The La Trobe ethnographic historians - Greg Dening, Rhys Isaac and Inga Clendinnen are the most eminent-were inspired by the conceptually informed interpretations Clifford Geertz had demonstrated in anthropology. In fields that were notably colonial-Mexico, Virginia, remote Pacific Islands-they showed how reading episodes and actions could create extraordinarily insightful history. Liberating genocide from a specialty into the largest and most detailed historical discourse means persisting with the idea that in studying particular actions and situations we can illuminate large historical processes and that (dialectically rather than conversely) large conceptions of historical process can illuminate episodes and actions. My hope is for a discourse where the processes of genocide are brought into focus-even if the word is avoided-in a way that makes the appropriate naming of the destruction not only difficult to avoid but clearly useful to historical understanding.

All of us know a too similar story of destruction in too many places. We know we have to keep refining our interpretations from the general to the particular: different encounters, different treaties, different apologies, different peoples. And from the particular we can refine our broader theses. Here's a story that should encourage us - and warn us: 
"I would have to make the necessary adjustments in my techniques of escape. I was already in the province of Polesie. The peasants here, who are called Poleshuks, speak the White-Ruthenian language. They are poor and suspicious. Often their numbers are decimated by disease, the most common of which is a sickness called koltun. The hair becomes matted with blood and sticks to itself like a wig. The peasants heal it with an extract of plants."

These strange humans are not in Paraguay or Papua. This is Poland; Raphael Lemkin reporting on his own country and its cauldron of different peoples. The encouragement is Lemkin's curiosity about uniqueness and otherness. The warning is in making otherness a curiosity. The main message turns out to be an almost universal one.

"These peasants looked at the unexpected visitors from Warsaw with curiosity and hostility. It was impossible to rely on them long for shelter and food. I decided to stop at the small towns, whose inhabitants, part Polish and part Jewish, appeared to be more tolerant of us. The Christians there could not define their ethnic origins or nationality. They referred to themselves very simply: 'We are from here."' ${ }^{9}$

Other ethnographers, among strangers far from the Europe they thought they knew, noted the tendency of Native Americans, Maori and other Pacific Islanders to refer to themselves simply as the human beings. This would not have surprised Lemkin, whose life work, we tend to forget, was to construct a common humanity out of all the diverse and often hostile groups who saw their own humanity as more immediate and important than anyone else's. In his own case, he knew, that intimate sense of a whole humanity came from the Jewish provincial culture that would be extinguished by the Nazis. His determination "to outlaw the destruction of human groups" was re-ignited by the situation of his own family, furtively visited for the last time. He won from his mother her blessing to leave and continue his work-with, of course, a wife and family of his own. He would fail her there, but before long he was in Sweden and within five months mastered enough Swedish to lecture at the university. He "rejoiced in being able to add the understanding of a new culture to my intellectual treasury." And he remembered the words of Victor Hugo: "As many languages as you know, as many times you are a human being." 10

Understanding how human beings were devalued, how humanity's richness was trashed, has not depended on Lemkin's concept. Greg Dening studied the cultural destruction of indigenous society in the islands we now call the Marquesas. To the people who lived there the islands were simply the land; they themselves were self-evidently Enata, the men, the human beings. They had customs that horrified the various Europeans that arrived on their beaches. Most notably, they were exuberant cannibals. The Europeans, from Britain, from America, more permanently from France, would not give up on teaching them civilization. They imported the standard colonialist version: an almost incomprehensible Christianity, an alien state authority, firearms (the boasting spear) work, school, alcohol. Everything about the indigenous world was turned upside down. Time was no longer the sun, the moon, and the seasons. It was a new tyrant: the clock. Space was no longer the island with its mountains and valleys and the plentiful seas between. It had brought another tyrant: an unknown power from an unknown place an unimaginable distance away. The intricacies of peace, between peoples and valleys, no longer mattered and the traditions of war, savage and bloodthirsty, were at once stimulated by the new vices of gunpowder and alcohol then finally suppressed by a much greater violence that killed by distant force, by degradation of belief and authority, by disease and drink. Within a century the old culture was destroyed and a terrible number of people as well.

His story of this encounter Dening calls Islands and Beaches: Discourse on a Silent Land. It is an elegy of a kind, and a discourse of many sophisticated concepts. After each chapter in the story there is a reflection: for instance, after Violent Death comes On Civilizing. He refers to Elias, and the deep doubts of Herman Melville. ${ }^{11}$

The one word you will not find is genocide. The word has kept me intellectually apart from my La Trobe friends for all our years together. Perhaps everyone here has heard the same, very frustrating explanation: I just don't think it's appropriate. Greg did not explain at all, but his work showed me where the deep difference lies. To an ethnographic historian the challenge begins with the action: what are these people up to? To create understanding of this at first strange behaviour we employ, as Geertz enjoined us to do, the widest range of "made-in-the-academy concepts."12 
I have come to think the resistance to genocide as one of those concepts is because it generally appears to get things back to front. The suspicion is that we start with the word, not the action. Once something is labelled (our critics tend to say) as genocide, enquiry does not seem to be opened up, it is closed off. ${ }^{13}$

The resistance to Lemkin's word as a bridge to understanding is not without reason. The fact is: genocide has never been a made-in-the academy concept. It was produced in one of the most extraordinary feats of individual activism, a much more lonely journey than that of Wilberforce in his campaign against slavery. However, it shares with slavery the problem of being a descriptive noun before it is a hermeneutic one. So we have a very big concept, designed for a very big crime. Business people like to quote the maxim that for every complex problem there is an answer that is clear, simple and wrong. That worries historians, too. Ned Blackhawk is now at Yale, a centre of Genocide Studies. His Violence Over the Land has imagination, ethnography, at times extermination - but not genocide. He prefers "genocidal" as an adjective, in the hope it can keep the bridge open. John Demos has just published another brilliant book that works out from one short-lived experiment, The Heathen School in Connecticut, to the widest reaches of American commerce in the 18th century, to China and Hawaii, and all the way to the Trail of Tears. Two of the leaders, John Ridge and Elias Boudinot, were educated at that school. They helped establish Cherokee institutions and exactly the kind of prosperous farming economy Jefferson said was essential for their survival. It did not save the Cherokees from the neighbours who wanted their land and cared little for their lives. Demos, too, is a Yale man, but unconnected with genocide studies. He has read the important histories of the Cherokee removal. He goes as far as ethnic cleansing, no further. ${ }^{14}$

Distinctions and word meanings (without even beginning on translations) are the very stuff of interpretation. About the time I encountered Geertz I was also much influenced, especially in my adoption of relations, by what remains one of the best books on Marx's deployment of concepts. Bertell Ollman in Alienation foregrounds a line from Pareto. Marx's words, he said, are like bats: one can see in them both birds and mice. I would like the non-legalistic use of some of Lemkin's own concepts-intent, interests - to have some of that elusive quality ${ }^{15}$ However that may be, it won't work with genocide itself. We really do need to know what it means, and if there are different understandings we need to know where they come from, what they define, and in which contexts they are useful. The most contentious field is settler colonialism.

\section{Redesigning the World: Colonialism and Genocide}

To re-examine the vast complex of interests, intentions and consequences in colonial genocides is the purpose of a book I am presently working on. It is called The Destruction of Peoples. The subtitle, provisionally, is Colonialism and Genocide in Britain, the United States and Nazi Germany. My aim is to find episodes in these already large cases that will support a larger interpretation about the colonizing impulse, its claims to be civilizing, its genocidal devastation in practice. It is turning out to be less ethnographic than I intended. Like most of us in the field, I find it hard to go past statements of intention and the kind of clear policies Lemkin started from. Such clarity about intentions has been vital in the legally enforceable progress of genocide definition; it only ever tells part of the story in the tangled actualities of historical encounters. I have always appealed for the reading of actions as intentions and have seen that as the special strength of ethnographic history. The actions must be read in the light of larger relations construed with the help of theory. Interpreting actions and elucidating their context is the activism of historians.

My first plan for the book was to go backwards from the Nazis. Barbaric civilization was not invented by them; they claimed a very distinguished heritage. Hitler told his dinner guests, "I don't see why a German who eats a piece of bread should torment himself with the idea that the soil which produces this bread has been won by the sword. When we eat wheat from Canada, we don't think about the despoiled Indians." ${ }^{16}$ The challenge is not only to follow through the ideology - that has been done quite thoroughly-but the dynamics of colonialism, the relations of genocide, as the bearers of European progress conquered the world. Jürgen Zimmerer has reiterated how completely the grand plans to colonize the Slavic, savage East was meant to serve Nazi ideological claims. They spoke emphatically of redesigning the whole of Poland, Belarus and Ukraine. Polish land divisions would not do for German settlement, "a total colonizing act is 
necessary."17 It was for this enterprise that Lemkin coined the word genocide: Axis Rule is about the ruthlessness of German colonization as it was already being practiced around him in before he fled. And as Lemkin learned very early on his flight, not just one people was being redesigned out of existence but many different peoples.

Far from Europe, the total colonizing act was promoted as civilizing. Unlike Axis rule, it was almost always believed to be of benefit to the conquered - as long as they fitted the grand design. Killing the indigenous peoples encountered by the colonizing adventurers was quickly recognized as a problem. Civilizing them was not a problem: it was the solution. Now we see what few could then see: civilizing was also the problem, indeed the larger problem. With ruthless theft of land came killing, social disruption and displacement. For the survivors there was further coercive civilizing - the cultural destruction of peoples. To understand that genocidal process we have to understand the culture of the civilizers and destroyers and the perspectives of those subject to their rule. Las Casas railed against the destroyers but he himself belonged to the civilizers. The difficulties of seeing destruction in civilization did not begin with the conquistadors and did not abate with the colonizing conquests that followed them. ${ }^{18}$

Lemkin went back to ancient times, as Kiernan did more recently..$^{19} \mathrm{I}$ am most concerned with the great British (and North American) experiment of the nineteenth century. The colonizers who claimed so much of the globe, not quite in a fit of absence of mind, preferred, in that British way, not to examine their motives or purposes too closely. But there was one group, evangelical Christians, who eventually insisted on taking moral stock. Out of the antislavery movement in the late 1700s, and just after the loss of the American colonies, came concern about the peoples they called native in the remaining colonies. The House of Commons Select Committee Report of 1837 is the key document publicizing British genocides a century before Lemkin invented his word. The men - all men of course, on this committee-wanted their government to acknowledge what was happening on every frontier of Britain's empire and to do something about it. In taking on the slave traders they had confronted England's most powerful commercial interest and won. Surely they could stop the depletion of those peoples who even as savages were all God's creatures and part of humanity. Some were already extinct, everywhere their decline was dramatic. In Australia, the Committee was told, the Aborigines round Sydney seemed mysteriously to "decay." "Wherever Europeans meet with them they appear to wear out...they diminish in numbers: they appear actually to vanish from the face of the earth." In Canada, the Cree, once so powerful "have now degenerated into a few families' from perhaps 10,000 to at most 300. There was an expectation of 'the remnant being extirpated in a short time if [note this] no measures are taken to improve their morals and to cultivate habits of civilization." A habit they did not need was their introduction to "spirituous liquors." Committee chair Thomas Buxton knew all about this peril; he helped run the largest brewery in Britain. But on this occasion the chief remedy was highlighted: Christianity was always the start. ${ }^{20}$

There may have been no hypocrisy in the Committee's anguish, but no confidence either. Intellectually and psychologically the parliamentarians appear to have suppressed awareness of a fatal bind: that civilization, the only remedy for genocide, would itself have genocidal consequences. It took many damaged generations in Australia and Canada before the disaster could be acknowledged, that it was a kind of killing, to kill the Indian in the child. When Stephen Harper, a later evangelical Christian, said sorry, did he understand this maxim any better than his forebears? And have we as historians yet done enough to create understanding of what it meant? A key difficulty in changing awareness is the correspondence between the ideas current in colonial democracies now and those evident at the time of colonization. Most of the concepts we need to apply-ignorance, ideology, interests, identity-have interconnections that underlie intent. Perhaps because we share so many assumptions built into these words we find it hard to credit intent to destroy. Our own interests, our own identities do not have genocidal implications; could it have been true then?

Here, I want to persuade you, ethnographic history comes into its own. The answer to Günther Lewy's question, "Can there be genocide without the intent to commit genocide?" must continue to be the "thick description" of incidents, interests and policies with genocidal consequences, even if, or especially if, no genocidal intent was announced. The "dark vanishings" of peoples subject to colonialism are not to be dismissed as "fatal impact" or "the price of progress." They are disasters that historians must explain..$^{21}$ 
Often enough, we also have explicit pointers of ideology and interests very close to intent. An influential writer with a very large audience visited Australia in the 1870s. He did not omit the dwindling population of Aborigines. "Their doom is to be exterminated; and the sooner that their doom be accomplished - so that there be no cruelty - the better will it be for civilization." His foxhunting and London club friends called him Tony Trollope, and he had already consigned the Indians of Canada and the United States to the same fate. "The latter people has been, or soon will be, exterminated-polished off the face of creation, as the Americans say-which fate must, I should say in the long run, attend all non-working people. As the soil of the world is required for increasing population, the non-working people must go. And so the Indians have gone." The Indians would not work in the new economy: their fate was to be "exterminated."22 Trollope's characters and his confident travel propaganda affirmed his own identity and imposed a victim identity on others. His generally benign ideology - here is just one of many places where I follow Marx-helped disguise interests. The interests of Trollope's ever increasing settler population were the interests of a whole civilization. Interests leave a trail we as historians can follow to groups and individuals who might share responsibility for deaths far from home. ${ }^{23}$

Civilizing, needless to say, does not appear in the Genocide Convention and it remains a document of mixed blessings for indigenous peoples. It does nominate child removal as genocidal, but does not highlight the purpose or the consequences. Andrew Woolford has made a strong case for not applying the Convention as a universal grid in what happened to indigenous peoples, where assimilation might be as important as extermination. To comprehend their experience and understandings is a completely different challenge from proving intent to cause mass death. The cultural damage Woolford calls ontological genocide was very much what Lemkin had in mind. We now have to liberate his word to encompass the catastrophes of colonialism the imperial powers were not ready to address in 1945. The challenge is to change a public consciousness through many private changes in awareness, so as to liberate genocides that happened in Australia, in Canada, in the US, from suppressed shame into acknowledged history. ${ }^{24}$

\section{Relations of Genocide Revisited}

Indigenous experience; civilizing and plainly genocidal intentions; economic interests and ideology; developments in technology communications and commerce on a global scale: what is the best way of connecting all these elements to create understanding? There is no one answer. In 1987 when I began talking about land and lives in Australia as relations of genocide I could see one path towards an answer. I continue to defend the more dynamic relations in preference to structures'that Adam Jones, Patrick Wolfe and others have kept very much in play. ${ }^{25}$ I don't have an answer to how the pursuit of private interests creates the huge alienated power of capitalism, nor did Locke, Ricardo or Adam Smith. Marx spent a lifetime on it. It is most of a lifetime ago that I had to answer exam questions on the Whig grandees and how their patronage controlled British parliaments and governments. I couldn't ever answer those questions. But I do have an answer to how they matter in what I'm calling the liberation of genocide. If you spend only five minutes at the Wikipedia entry for John Locke, meeting his patron the Earl of Shaftesbury, hearing him in discussion with John Dryden and Isaac Newton, and accompanying the future queen from Holland to England, you get a sense of what spread of history might be relevant here. I don't need to tell you about Locke's direct influence on the founding fathers of the United States.

The original title of my book was to be Jefferson's Genocide (I'm now saving that for later) and the argument for changing it was that it would simply be too distracting or even cause some people not to go near it. Yet the southern and westward expansion of the United States is perhaps the most promising field for trying to trace the relations of genocide beyond the frontier rhetoric of Indian removal and extermination. The patriot heroes George Washington, Thomas Jefferson and Patrick Henry were also heroes of land speculation and Native American displacement. They pushed out the frontier to create an ever-larger proving ground of Locke's ideology.

We do need to go back to John Locke. And, on the vast proving ground, to Frederick Jackson Turner. Like Marx he is severely out of fashion, not because of specific debates about the frontier but because of the ambition of his enterprise. 
The United States lies like a huge page in the history of society. Line by line as we read this continental page from West to East we find the record of social evolution. It begins with the Indian and the hunter; it goes on to tell of the disintegration of savagery by the entrance of the trader, the pathfinder of civilization; we read the annals of the pastoral stage in ranch life; the exploitation of the soil by the raising of unrotated crops of corn and wheat in sparsely settled farming communities; the intensive culture of the denser farm settlement; and finally the manufacturing organization with city and factory system. This page is familiar to the student of census statistics, but how little of it has been used by our historians. ${ }^{26}$

We might say the same about historians of genocide. It is daunting to integrate the destructive pressures of these huge economic and societal developments with the creative energies of America. Turner's bold project, to interpret the meaning for his society of its uniquely rapid roll out of modern technological civilization from sea to shining sea, did not neglect its impact on the indigenous peoples in its path. The new farming frontier meant that the forests were felled, the game driven away-or slaughtered - and the people, too. In the century since Turner there has been a great deal of powerful writing on the experience of individual peoples and the ideology of expansionist progress. There are many searching explorations of the meeting of old and new, some on Richard White's middle ground. But you will not find a great deal about genocide in White, or Limerick, or Worster. You will find more, with more affecting immediacy, in Jeff Ostler on the Sioux, or the classic writing of Dee Brown or in Burns' and Ives' TV series, The West. ${ }^{27}$

When I was recently trying to make sense of how just one encounter in the middle of the continent, the coming of the cattle industry to Indian Territory, later Oklahoma, I found the TV series grounded me more intimately and with more historical scope than most of the writing. It is an involving introduction to Native American perspectives, with Sitting Bull, Scott Momaday and others. Like the historians who have not shied away from big movements of people and capital, animals, machines and ideas, it lays out the scale and complexity of the continental conquest. What I'm looking for is a convergence between close-up studies, ethnographic interpretation, genocide theory, and the large canvases of Walter Nugent, James Belich and John Weaver. ${ }^{28}$

There are some special features of these books that appeal to me. They are not comparative histories, and they are not the old fashioned histories of empire my generation could not stomach when we were students. They each have a different balance between narrative and interpretation. There's a lot to learn from Nugent and a great deal to inspire further enquiry in Weaver. He ranges from ecology and economy to the political order and sociology of the colonizing powers and the cultural understandings that made possible, as he says, "the messy convergence of private impertinence and the coercive might of the state." As the history of the great colonial corporations is re-assessed we will find the convergence of private and state interests was not just messy for indigenous peoples but lethal as well. For the colonialist state that coloured so much of the map pink, Great Britain, he quotes Richard Grassby's formula, that "the assimilation of all potential rivals by the landed gentry created a united propertied interest which embraced business, agriculture and the professions." ${ }^{29}$ Washington and Jefferson could not imagine a new nation apart from that gentry ideal. Jefferson set out to assimilate the Indians into it as well.

These historians are less blunt than Chris Powell: they do not say "Genocide in the modern era has its roots in the very constitution of society, in the civilising process which has generated both the sovereign state and the sovereign individual subject." ${ }^{30}$ But they keep pushing us to connect all those histories of Jeffersonian philanthropy with historical relations of genocide. Sociology has been in genocide scholarship since the beginning, yet the sociology of genocidal societies (with the exception of Germany) remains the least connected to the scholarly discourse of genocide studies. The connecting historians are few, and not all of us need to theorize the contradictions and dialectics but there are inspiring examples of how they can be teased out. Ronald Takaki is exceptional. He combines a long, wide view with deep explorations of society, psychology and his own genocide consciousness. ${ }^{31}$ It is for us to pursue the project of understanding genocide in its largest context, over time (modern history), movement (transfers of population with their complete societies), and space (global). I do not think we can ever understand what happened in so many terrible encounters in thousands of incidents without entering into the process that used to be called progress. We have to engage with the challenge so as to liberate genocide into the most ambitious historiography. 


\section{History Work and Genocide Awareness in Australia}

By and large, Australian historians have not tried to interrogate the categories of conventional historiography. Aboriginal peoples were sometimes excluded, sometimes included but very rarely followed into a deeper enquiry of European settlement. There were no Aborigines before there was an Australia. The most totally colonizing act, justifying the supplanting of indigenous peoples, was the imposition of an imported system of meaning. Every place of significance, often deep religious significance, was casually (but legally) renamed, and usually appropriated by a newly-arrived vandal who had trampled it with strange animals or fenced it off. Can a name be an instrument of genocide? Quite fundamentally. Can a fence be an instrument of genocide? Of course, if it helps destroy something that gives a people the meaning of their existence. "Capital on four hooves" to a pastoralist is an alien tank armed with destructive tracks to an Aboriginal custodian of a waterhole. Thirty years ago Ross Gibson made a powerful film called Camera Natura. In it he shows two representations of country, one a central Australian dot painting, the other a settler survey showing the right angles of properties and straight boundary lines. "Whoever can read one map," we are told, "cannot read the other." ${ }^{32}$ To this day, though most Australians would proudly recognize a Central Australian dot motif on a Qantas jumbo, almost none would be able to even guess which Central Australian people developed that art-and we're talking about a living people with their own language and identity. Then there are all the peoples of whom not one member is left alive, and those whose last speaker of language is soon to die. These are the 'Blackfulla' terms in English: 'language', 'country', 'law'. If no one speaks language, how can knowledge of country be continued, who will know the law? As in the case of the two maps (whoever can read one cannot read the other) we need to stimulate a sensibility that can appreciate how an indigenous sense of time, place and movement is so fundamentally at odds with a settler one. ${ }^{33}$

The great Australian anthropologist W. E. H. Stanner, who fought the first battles to change popular consciousness of Aboriginal cultures, coined the term 'everywhen' to indicate the different temporal and spatial significance of what was too easily translated as 'the dreaming'. The poetic term went with an ethnographer's explanation: it was 'a kind of narrative of things that once happened; a kind of charter of things that still happened; and a kind of logos or principle of order transcending everything significant for Aboriginal man.' How could non-Indigenous Australians ever access that world? Stanner kept trying: 'the worst imperialisms are those of preconceptions', he wrote, and he knew how destructive preconceptions could be. After all, he grew up in a time when Aborigines were generally considered 'a dying race' and verses such as this were standard fare:

Her shield unsullied by a single crime,

Her wealth of gold and still more golden fleece,

Forth stands Australia in her birth sublime,

The only nation from the womb of Peace. ${ }^{34}$

The many radically different points of view, the indigenous ones, can be only partially construed by even the most sensitive ethnography, even though colonizers expected conquered peoples to make sense of European perspectives as a matter of course. Stanner said that asking Aborigines to adapt on our terms was asking them to 'unbe'. To have a place in the market economy they would have to leave a culture whose values, unlike ours, 'were determined once for all in the past.' But the adaptation that seemed impossible without a virtually genocidal assimilation now seems taken for granted. In Australia there is a renewed optimism that Aboriginal communities and individuals are finding ways beyond survival into initiative, enterprise and prosperity. What Stanner and others hoped to preserve as their culture is of course giving way to a new culture, still destructive for many but with the audacity of hope.

Importantly for us, it involves a changed orientation towards the past. There is little appetite for discussions of genocide among the intellectuals and leaders of Indigenous Australia. If pressed, some might say they have entered a post-genocidal history. Free adaptation to changing historical circumstances, even coercive colonial circumstances, was never part of Lemkin's definition of genocide. In part, some point out, that was because he needed the support of colonial powers, 
in part because (like Hannah Arendt) he shared the idea of civilization they proclaimed. He also believed-as some indigenous peoples did from first contact-that the benefits of European civilization were just that: clear benefits. For me, rather late in the day, this has meant returning to my own neglected national history.

I am an Australian citizen born in New Zealand. Growing up in Dunedin-hence my mainly Scottish identity - we lived in the suburb of Maori Hill. It didn't strike me as the least bit odd that my classmates at Maori Hill School included only one Maori family. The Paratas, like the Bartas, might have been that little bit different but not really. We all trotted along to the forbidding rows of portraits in the Otago Early Settlers Museum, whole walls of bearded city fathers, and the model of a local Maori pa in the big Museum..$^{35}$ It had long gone, like the giant Moa in the diorama nearby. Only in recent months have I gone back to New Zealand history with the question: why was I never told about the genocide?

Very few Maori-you can check this on the web-would want to tell me about a genocide. Yes, all agree numbers at least halved in the century after European arrival, from over 100,000 to 47,000 , partly because of disease, partly because the enthusiastically acquired muskets hugely increased the casualties of Maori warfare. Then the disruptions of dispossession, warfare against the British Empire, and yet more dispossession. At the end of the $19^{\text {th }}$ century there was much talk about 'the passing of the Maori'. But at the very same time Maori numbers were increasing again and the determination to save the cultural structure of Maori identity was strengthening. It could be said there was no genocide in New Zealand because the Maori fought the settlers to a standstill, but even there it involved very creative adaptation to new technology and new principles of law and language. With the advantage of one language, Maori quickly embraced both Christianity and literacy. Mission and government schools taught in Maori until the Maori insisted on English. Now all government departments are named in both languages. ${ }^{36}$

We are a long way from there in Australia. It is a struggle to have any Indigenous children taught in their first language. There were perhaps 750 Aboriginal languages in Australia. Most have gone. All are threatened. First on the missions, then by removing children for assimilation, there was an officially sanctioned policy of destruction. Perhaps 25,000 children - up to one in threewere forcibly removed between 1910 and 1970. Few families were not affected. ${ }^{37}$ It was not only a policy of cultural assimilation, it became quite generally acknowledged among its proponents as a biological campaign, indeed a final solution. Australia would become homogenous, and white, by 'breeding out the colour'. The focus was on removing "half-caste" children, or those with an even greater fraction of "white blood", especially girls. "Full-blood blacks" would die out anyway: the "solution" to the problem of a growing mixed-race population was to steal the children, keep them from contact with their Aboriginal families, and marry them to Europeans. A 1937 Canberra conference was assured that in 50 years time everyone would be able "to forget that there were ever any aborigines in Australia." ${ }^{38}$

Aboriginal people disappeared from view for the best part of a century. As the peoples actually disappeared in the South East, consciousness of what had taken place went with them. And, as in Canada, it is without doubt Aboriginal activism and images of a much larger population in the north, that brought successive bouts of media and mainstream attention. On each landmark occasion, the 1967 referendum on including Aborigines in Commonwealth responsibilities (still popularly misrepresented as 'when Aborigines got the vote'), the Land Rights movement of the 1970s and 80s, the Deaths in Custody Royal Commission of 1987-91, and the Stolen Children report of 1997, it was Indigenous insistence that broke through TV trivia, wall-to-wall sport, the clamour of kids, paying the mortgage, and politics as usual. An exception was the 2007 'Intervention' in the Northern Territory. In response to reports of endemic child abuse the army was sent in and welfare was controlled against the protests of Aboriginal communities. While a few voices spoke of continuing genocide, the Australian majority had an attitude dominated by images of, one might say, auto-genocide: the continuing alcohol abuse, drunken violence, and youth suicide.

The images and realities of Aboriginal destruction and self-destruction are being confronted with a new tone among Aboriginal leaders. Alcoholism and drug abuse as survival mechanisms evoke less sympathy. There are practical issues to be tackled in the health and judicial systems. The world's most incarcerated people have chronic illnesses and an intractable gap in life expectancy. 
But the absence of genocide from the discourse is as marked among Indigenous commentary as it is in conventional history. Genocide is being liberated from Black consciousness because there are more important matters to get on with. That Indigenous agency has trumped victim history decisively among Aboriginal intellectuals may have interesting consequences for genocide studies. Indigenous peoples can decolonize from our concept but we are stuck with it. ${ }^{39}$

For us, the heirs of colonialism, the history remains a matter too important to let go. The way forward, I'm coming to think, is not to keep insisting on the recognition of genocide but on the recognition of our connection to the historical realities whether they are so named or not. The connection between past and present was a key one in the relations of genocide I hoped Australians would come to recognize.

In 1984, Don Watson published Caledonia Australis: Scottish Highlanders on the Frontier of Australia. ${ }^{40}$ The Scots were his own forebears and the frontier was the district where grew up, to the east of Melbourne. The book centres on Angus McMillan, and in the many ethnographic illustrations I recognized some of my own heritage as well. Looking so like my uncles in Dunedin, the new laird of Gippsland, benign and influential in his later years, had a murkier past. As an immigrant landholder he organized the Highland Brigade that perpetrated the biggest massacre in Australian history. His friends and neighbours murdered more than a hundred peaceful Aborigines camped by a waterhole. They turned it red with blood.

In colonial Australia the settlers called it 'dispersing' the Blacks. Watson plainly called it genocide and in this case traced its origins to the prior dispersal of the Scots Aborigines (as Marx called them) in the Highland clearances. That event, with its own history of inexorable interests and ruthless atrocities had global origins and global effects - in Canada, the United States and New Zealand as well as in Australia. Caledonia Australis has been republished twice but has never had the influence I hoped it would have. Several books later Watson has written The Bush: Travels in the Heart of Australia, where he again begins with his family memories then moves through landscape and nature and history towards a national 'we', a collective that has had responsibility for the country since European settlement displaced the Aboriginal peoples who cared for it. There are some direct and confronting references to the destruction of lives and land but its effectiveness is in an even more ambitious kind of ethnography, one that includes the reader in its large reflective enterprise. It has been a popular and prize-winning success. Through a poetic array of stories and observations the book illuminates a culture of taming the land in a rush of appropriation, where the hard life of establishing new animals for a new population made the deaths of the earlier possessors seem close to inevitable. The facts related and alluded to do not have to be named as genocide for the reality to make undeniable historical sense. Watson, known as a commentator on plain language, chose not to deploy the word. Yet none of the reviews (overwhelmingly positive and easily located on the web) have any doubt about the story told. ${ }^{41}$

For a time, Watson had another career. He wrote speeches for the Labor Prime Minister Paul Keating. One of them, in 1992, will live as the most direct facing of Australia's dark past in the two centuries of British occupation. ${ }^{42}$ The immediate audience was a Sydney gathering of mainly Aboriginal people in Redfern Park. They were not prepared for the words that would resound far beyond their community. The larger audience, the national one, was even less prepared. They were used to references to 'our' country and our history. They were quite unaccustomed to the 'we' the Prime Minister would repeatedly ask them to belong to. He would ask them to directly face, and own, Australia's genocidal past. And he did it-this, to me, is critically important-not by citing texts of evil intent but by going back to the actions.

The starting point might be to recognise that the problem starts with us non-Aboriginal Australians.

It begins, I think, with that act of recognition.

Recognition that it was we who did the dispossessing.

We took the traditional lands and smashed the traditional way of life.

We brought the diseases. The alcohol.

We committed the murders.

We took the children from their mothers. 
We practised discrimination and exclusion.

It was our ignorance and our prejudice.

And our failure to imagine these things being done to us. ${ }^{43}$

The emphasis on imagination in the Redfern speech was inspired. It recognized the kind of heightened realities we all live in and which make it close to impossible to recognize the realities others live within. We can see this incapacity as a common factor in everyday life, and in every genocide. 'We failed to ask,' said Keating, 'how would I feel if this were done to me?... It might help us if we non-Aboriginal Australians imagined ourselves dispossessed of land we had lived on for fifty thousand years - and then imagined ourselves told that it had never been ours. Imagine if ours was the oldest culture in the world and we were told that it was worthless. Imagine if we had resisted this settlement, suffered and died in the defence of our land, and then were told in history books that we had given up without a fight.'

Kevin Rudd's 2008 apology to the stolen generations, like Harper's apology the same year, would earn more credit as a healing acknowledgement of cruel policies. It was less direct about assimilation - unlike Canada's reference to 'kill the Indian in the child' - and carefully did not confront Australians with the full reality of their past. It was resoundingly silent on the genocide that founded the nation.

The word genocide was not in Keating's Redfern speech, either. The tactical, perhaps strategic, wisdom of by-passing Lemkin's term was borne out when it was thrown in the faces of Australians by the 1997 Bringing them Home report on the Stolen Generations. That the Australian report cited child removal as genocide within the meaning of the Convention caused outrage and thousands of spilt words in the phoney 'history wars' between those accused of promoting a 'black armband' view of the past and commentators who were much more evidently wearing a 'white blindfold'. ${ }^{44}$ As academics, we are familiar with the silos within which (rather than between which) discourse takes place; in the public sphere debates in the media (old as well as new) almost always reinforce the echo chambers of prejudice. The campaign caused 'genocide' to be locked up afresh as a pariah word, not to be used of Australia. For most Australians, it is not to be liberated to this day. For those of us concerned to see its apt usage in general discourse the question might become: is it more important to liberate the word or the consciousness? The Redfern speech is a beacon.

Indigenous voices might also help us find our own. Stanner recorded the attempt of an old Aboriginal man to imagine the mental world of the destructive newcomers.

White man got no dreaming

Him go 'nother way.

White man, him go different.

Him got road belong himself. ${ }^{45}$

There was similar Native American incomprehension when the buffalo were being slaughtered. 'Has the white man become a child, that he should recklessly kill and not eat?'46 I do not think it is too extreme to relate destruction of our own species to our inability to connect with every other species. That connection was something Europeans, even Charles Darwin, found most surreal about the indigenous peoples they encountered and called savages. The genocide they rained on them was fed by a certain view of nature, blotting out all earlier human experience of living in the natural world. Perhaps now we will listen to the voices they tried to silence. The white man's road now threatens not just the invaded peoples but all peoples. The accelerating ecological disaster has been linked to genocide by Mark Levene, Jürgen Zimmerer, Damien Short and others. ${ }^{47}$

The context of modern genocide was always the whole globe, now finally in plain sight as a planet, the lonely planet we all have to share. It is an historic opportunity genocide scholars should seize: we are the experts, sadly, in mass destruction. What do we say about responsibility for the causes and effects of climate change? About poverty, overpopulation, over-consumption, monoculture agribusiness, heedless 'development'? About persecutions, wars, sexual violence, and the reasons for desperate migrations?There are known effects and unknown ones. With whatever means we choose we must keep trying to reach those who know nothing about the work we are 
doing here. What we are doing is too important to let go-and too important to keep to ourselves. We have had thirty years of creating Genocide Studies. Even as we celebrate-and we should - we must liberate genocide from historical distortions, from restriction to a reductive legal concept, and from containment in an academic specialty.$^{48}$ Our objective now, overcoming differences of starting point and vocabulary, must be to engage more widely with all who care about the destruction of peoples and the cultural losses to humanity. Genocide, sadly, belongs to everybody and in the next thirty years we, you, have to write the kind of histories that make sure everybody knows why that matters.

Tony Barta is a Research Associate at La Trobe University, where he taught European and Australian history and founded the History and Film program. In addition to his pioneering work on genocide in Australia, he has written on twentieth-century Germany and on media and historical understanding. His overview of genocide scholarship in Australia is in Dan Stone (ed.) The Historiography of Genocide (Palgrave Macmillan, 2008)

\section{Acknowledgments}

This article originated as a keynote address at the 2014 Conference of the International Association of Genocide Scholars at the University of Manitoba. I am indebted to the organizers and the participants, and to continuing discussion with colleagues.

\section{Endnotes}

1 'After the Holocaust: Consciousness of Genocide in Australia', The Australian Journal of Politics and History, 31, 1 (1985): 154-161; special issue ed. Konrad Kwiet and John A. Moses. Later I was told that Charlie Perkins, Australia's first Aboriginal university graduate and first Indigenous head of a government department, had spoken to the Hakoah audience the week before me. He knew how to deal with people and didn't offend anybody, though twenty years earlier he had been more confrontational when he led Australia's first Freedom Ride.

2 Alexander Laban Hinton ed., Annihilating Difference: The Anthropology of Genocide (Berkeley: The University of California Press, 2002) Introduction, esp. pp. 1-6. See also the editors' Introduction to Alexander Laban Hinton, Thomas La Pointe, and Douglas Irvin Erickson eds, Hidden Genocides: Power, Knowledge, Memory (New Brunswick NJ: Rutgers University Press, 2013), 1-17. The opening question, 'Is slavery genocide?' receives a forthright answer.

3 For a guide to the debates, and to Lemkin's own interpretation, see Ann Curthoys, 'Genocide in Tasmania, the History of an Idea', in Dirk A. Moses (ed.), Empire, Colony, Genocide: Conquest, Occupation and Subaltern Resistance in World History, (New York and Oxford: Berghahn Books, 2009), 239-252. See also Rebe Taylor, 'Genocide, Extinction and Aboriginal Self-determination in Tasmanian Historiography', History Compass 11, 6 (2013): 405-41, and Rebe Taylor, 'The National Confessional', Meanjin Quarterly, 3 (2012): 22-36.

4 Tony Barta, 'Decent Disposal: Australian Historians and the Recovery of Genocide' in Dan Stone, ed., The Historiography of Genocide (Houndsmills: Palgrave Macmillan, 2008), 296-322.

5 Amy Lonetree, Decolonizing Museums: Representing Native America in National and Tribal Museums (Chapel Hill: The University of North Carolina Press, 2012).

Linda Tuhiwai Smith, Decolonizing Methodologies: Research and Indigenous Peoples (London and New York: Zed Books, 1999). On Lemkin and colonialism see A. Dirk Moses, ed. Empire, Colony, Genocide (Oxford and New York: Berghahn Books, 2008), especially the chapters by Moses and Docker. Lemkin made quite clear that the Nazi treatment of Poland was his paradigm of genocidal colonialism in Raphael Lemkin, Axis Rule in Occupied Europe: Laws of Occupation, Analysis of Government, Proposals for Redress (Washington, D.C.: Carnegie Endowment for International Peace, 1944).

The Winnipeg skyline is now dominated by the Canadian Museum of Human Rights, whose inception was itself not without controversy. A Dirk Moses, 'Does the Holocaust Reveal or Conceal Other Genocides? The Canadian Museum of Human Rights and Grievable Suffering', in Alexander Laban Hinton, Thomas La Pointe, and Douglas Irvin Erickson, eds, Hidden Genocides, 21-51. Moses questions whether the European focus of the museum does 'justice to the Indigenous experience-the most Canadian of them all'. See also Tricia Logan, 'Memory, Erasure, and National Myth' in Andrew Woolford, Jeff Benvenuto, Alexander Laban Hinton eds, Colonial Genocide in Indigenous North America (Durham and London: Duke University Press, 2014), 149-165; and Tricia Logan, 'National Memory and Museums: Remembering settler colonial genocide of Indigenous peoples in Canada' in Nigel Eltringham and Pam Maclean eds, Remembering Genocide (London and New York: Routledge, 2014), 113-130. 
6 For discussion of critical genocide studies, as led by Moses, Hinton and others, see the references in Alexander Laban Hinton, 'Critical Genocide Studies', Genocide Studies and Prevention 7, 1 (2012) article 3, 4-15.

7 Tony Barta, 'Living in Dachau: Bavarian Catholics and the fate of the Jews 1893-1943', in John Milfull (ed.) Why Germany? National Socialist anti-Semitism and the European Context (Providence and Oxford: Berg, 1993), 41-60.

8 John Docker, who also believes there is a danger of Genocide Studies becoming 'just another enclosed discipline', put it to me this way: Genocide Studies 'can only engage with its true subject, humanity, by engaging in constant conversations with the whole of the humanities.'

9 We owe these insights to the recent publication of Lemkin's autobiography edited by Donna-Lee Frieze. Raphael Lemkin, Totally Unofficial (New Haven: Yale University Press, 2013) 46-59.

10 Lemkin, Totally Unofficial, 75. On human groups as the basis of Lemkin's ideas, and on cultural destruction in colonization, see A. Dirk Moses, 'Raphael Lemkin, Culture, and the Concept of Genocide' in Donald Bloxham; and A. Dirk Moses, eds, The Oxford Handbook of Genocide Studies (Oxford and New York: Oxford university Press, 2010) Ch. 1, 19-41.

11 Greg Dening, Islands and Beaches: Discourse on a Silent Land. Marquesas 1774-1880 (Honolulu: University of Hawaii Press, 1980).

12 Clifford Geertz, 'Thick Description: Toward an Interpretive Theory of Culture,' The Interpretation of Cultures (New York: Basic Books, 1973) 28-29, retells a tale that bears more retelling. 'There is an Indian story - at least I heard it as an Indian story - about an Englishman who, having been told that the world rested on a platform which rested on the back of an elephant which rested in turn on the back of a turtle, asked (perhaps he was an ethnographer; it is the way they behave) what did the turtle rest on? Another turtle. And that turtle? "Ah, Sahib, after that it is turtles all the way down."' In Winnipeg it could not but remind me, in the repeated references by Native Americans to 'Turtle Island', of the distance between those who can still see themselves as dancing on the turtle's back and those who begin with the much newer continental nation of 'Canada'.

13 I am far from alone in noticing this problem: 'Although the word genocide was introduced less than seventy years ago, it has gathered enormous rhetorical power that often overshadows its critical utility.' Woolford et al, Colonial Genocide in Indigenous North America, Introduction, 2.

14 Ned Blackhawk, Violence over the Land: Indians and Empires in the Early American West (Cambridge, Mass: Harvard, 2006); and John Demos, The Heathen School: A Story of Hope and Betrayal in the Age of the Early Republic (New York: Knopf, 2014).

15 Bertell Ollman, Alienation: Marx's Conception of Man in Capitalist Society (Cambridge: Cambridge University Press, 1971), 3. See also Helmut Fleischer, Marxism and History (New York: Harper, 1973) for an interpretation that would make an integration with ethnographic history (and concepts such as genocide) productive.

16 Adolf Hitler, Hitler's Table Talk, 1941-1944, trans. from the German by Norman Cameron and R. H. Stevens, ed. H. R. Trevor-Roper (Oxford: Oxford University Press, 1988), 3, 37-8, 69. See also Mein Kampf, ch. 11 ('Nation and race'). For the many lineages of the Nazi imperial project, see Enzo Traverso, The Origins of Nazi Violence (New York: New Press, 2003), ch. 2 ('Conquest'); and on the important influence of the American example Carroll P. Kakel, The American West and the Nazi East: A Comparative and Interpretive Perspective (New York, Palgrave, 2011); and The Holocaust as Colonial Genocide: Hitler's 'Indian Wars' in the 'Wild East' (New York: Palgrave, 2013).

17 In Moses, ed., Genocide and Settler Society, 54-55.

18 For Lemkin's uncritical reliance on Las Casas see Michael A. McDonnell and A. Dirk Moses 'Raphael Lemkin as historian of genocide in the Americas', Journal of Genocide Research 7, 4 (2005): 501-529.

19 Ben Kiernan, Blood and Soil: A World History of Genocide and Extermination from Sparta to Dafur (New Haven and London: Yale University Press, 2007). Kiernan has taken care in the vast scope of his project to include 'extermination' - which may or may not count in a legalistic definition - and to emphasize, even in more legalistic interpretations, the reading of actions to reveal genocidal intent. Introduction, esp. 9-20.

20 The withering 1837 Report of the House of Commons Select Committee on Aboriginal Tribes (British Settlements) is available online in facsimile at https://archive.org/details/reportparliamen00britgoog.

'The mighty influence with which Providence has invested us, we have made the means of spreading devastation and ruin.' Preface, vii.

21 P. Brantlinger, Dark Vanishings: Discourse on the Extinction of Primitive Races, 1800-1930 (Ithaca, NY: Cornell University Press, 2003). See three responses, by Tony Barta, Norbert Finzsch, and David Stannard to Günther Lewy's 'Can There Be Genocide Without the Intent to Commit Genocide?' in Journal of Genocide Research, 10 (2008): 111-133. 
22 W.E.H. Stanner, White Man got no Dreaming: Essays: 1938-1973 (Canberra: ANU Press, 1979), 189, quotes Trollope, and says 'he probably spoke for a majority of Australians' in the 1870s. Anthony Trollope, North America (New York: Harper and Brothers, 1862), 350.

23 Tony Barta, “'He in whose interest it was, did it”: Lemkin's lost law of genocide', Global Dialogue, Vol. 15, No.1, 2013, available at: http://www.worlddialogue.org/content.php?id=544.

24 Andrew Woolford, 'Ontological Destruction: Genocide and Canadian Aboriginal Peoples' Genocide Studies and Prevention 4, 1 (2009): 81-97. David MacDonald has alerted me to James Miller's term 'aggressive assimilation' in his Shingwauk's Vision: A History of Native Residential Schools (Toronto: University of Toronto Press, 1996). See the chapters by Woolford, Patzer and MacDonald in Woolford et al. Colonial Genocide in Indigenous North America.

Of the many individual testimonies, one of the most insightful is Theodore Fontaine, Broken Circle: The Dark Legacy of Indian Residential Schools. A Memoir (Calgary: Heritage House, 2010).

25 Tony Barta, 'Relations of Genocide: Land and Lives in the Colonization of Australia', in I. Wallimann \& M. Dobkowski eds Genocide and the Modern Age, (Westport, CT: Greenwood Press, 1987), 237-252. Tony Barta 'On pain of extinction: laws of nature and history in Darwin, Marx and Arendt', in R. King \& D. Stone, eds Imperialism, Slavery, Race and Genocide: The Legacy of Hannah Arendt (New York: Berghahn Books, 2007). Adam Jones 'Genocide and Structural Violence: Charting the Terrain' in his New Directions in Genocide Research (London and New York: Routledge, 2011) 146-7. Patrick Wolfe, 'Structure and Event: Settler Colonialism, Time, and the Question of Genocide' in A. Dirk Moses, ed. Empire Colony, Genocide (New York and Oxford: Berghahn Books, 2008) Ch. 4, 102-132. For recognition of the more ambitious work underway see also the Introduction by Bloxham and Moses to their Oxford Handbook of Genocide Studies, 1-16.

26 Turner's 1893 thesis quoted from the 1921 edition (now online, no page numbers) in Tony Barta, 'A Fierce and Irresistible Cavalry': Pastoralists, Homesteaders and Hunters on the American Plains Frontier' in Mohamed Adhikari ed. Genocide on Settler Frontiers: When Hunter-Gatherers and Commercial Stock Farmers Clash (Capetown: UCT Press, 2014), Ch.10, 232-258.

27 Ken Burns and Stephen Ives, The West, 704 mins, 1996; Richard White, "It's your misfortune and none of my own": a new history of the American West (Norman and London: University of Oklahoma Press, 1993); Patricia Limerick, The Legacy of Conquest: the Unbroken Past of the American West (New York: Norton, 1987); Donald Worster, Under Western Skies: Nature and History in the American West (New York: Oxford, 1992.) Dee Brown, Bury My Heart at Wounded Knee (1970) Illustrated edition. (New York: Sterling, 2009. Jeffrey Ostler, The Plains Sioux and U.S. Colonialism from Lewis and Clark to Wounded Knee (New York: Cambridge University Press, 2004). See also the impressive two-part overview by Stephen Howe, 'Native America and the study of colonialism, Part 1: contested histories' Settler Colonial Studies Volume 3, Issue 1, 2013, 102-126, and 'Native America and the study of colonialism, Part 2: colonial presents', Settler Colonial Studies 4, 1 (2014): 105-119.

28 Walter Nugent, Habits of Empire: A History of American Expansion (New York: Vintage, 2009); James Belich, Replenishing the Earth: The Settler Revolution and the Rise of the Anglo-world, 1783-1939 (Oxford: Oxford University Press, 2009); and John Weaver, The Great Land Rush and the Making of the Modern World, 16501900 (Montreal: McGill-Queen's University Press, 2003). For a longer perspective see David Day, Conquest: How Societies Overwhelm Others (Oxford: Oxford University Press, 2008).

29 Weaver, pp. 5-11. On the limits of societal knowledge in a world only coming to grips with modern science and communications, Richard Grassby observes: 'Even a man of incomparable intellectual gifts, like Locke, was necessarily limited in his knowledge of the world; Locke probably knew less about his own society than the statistician Gregory King.' He is equally sceptical about pamphlets, theatre and diaries as sources for social realities. Richard Grassby, Kinship and Capitalism: Marriage, Family, and Business in the EnglishSpeaking World, 1580-1740 (New York: Cambridge, 2001) pp. 25-7.

30 Christopher Powell, Barbaric Civilization: A Critical Sociology of Genocide (Montreal: McGill-Queen's University Press, 2011).

31 Ronald Takaki, Iron Cages: Race and Culture in 19 $9^{\text {th }}$ Century America (New York: Oxford University Press, 1979); and A Different Mirror: A History of Multicultural America (Boston: Little Brown, 1993).

32 Tony Barta, 'Making it Strange: Ross Gibson's Camera Natura, David Perry's The Refracting Glasses, and John Hughes' One Way Street in Ken Berryman, Wayne Levy and John Benson (eds) Papers given at the Sixth Australian History and Film Conference, Melbourne, 1994.

33 Wikipedia numbers 27 language families and up to 750 distinct dialects when the Europeans came. Of those that survive seven retain between 1,000 and 3,000 speakers. Only in a few remote places are indigenous languages being learned by children. Walsh, Michael 'Overview of Indigenous languages of Australia' in Suzanne Romaine (ed), Language in Australia. (Cambridge: Cambridge University Press, 1992).

34 Percy Russell, 'The Birth of Australia', 1889, quoted in WEH Stanner, The Dreaming and Other Essays, Introduction by Robert Manne (Melbourne: Black inc, 2009), 9-10. 
35 James Cook was blunt about Maori conflict. 'I might have extirpated the whole race,' he wrote in his journal, 'for the people of each hamlet or village, by turns, applied to me to destroy the other.' Captain Cook's Voyages of Discovery (London: Everyman, 1948), 242, quoted in V.G. Kiernan, The Lords of Human Kind (Harmondsworth: Penguin, 1972) 273.

36 I am especially indebted to my La Trobe colleague Alan Ward for this late education in Maori-Pakeha relations. His book A Show of Justice: Racial 'Amalgamation' in nineteenth century New Zealand (Auckland: Auckland University Press 1995, first published 1973) is essential reading. See also James Belich, Making Peoples (Auckland: Penguin, 1996 and Ian Pool, Te Iwi Maori: a New Zealand Population, Past, Present and Projected (Auckland: Auckland University Press, 1991).

37 'Nationally we can conclude with confidence that between one in three and one in ten Indigenous children were forcibly removed from their families and communities in the period from approximately 1910 until 1970. In certain regions and in certain periods the figure was undoubtedly much greater than one in ten. In that time not one family has escaped the effects of forcible removal (confirmed by representatives of the Queensland and WA Governments in evidence to the Inquiry). Most families have been affected, in one or more generations, by the forcible removal of one or more children.' Bringing them Home. National Inquiry into the Separation of Aboriginal and Torres Strait Islander Children from their Families (Canberra: Commonwealth Printer, 1996).

38 Tony Barta, 'Sorry, and Not Sorry, in Australia: How the apology to the stolen generations buried a history of genocide', Journal of Genocide Research 10, 2, (2008), 201-214.

39 Marcia Langton, Indigenous Peoples and the Resources Boom, ABC Boyer Lectures, 2013; Noel Pearson, A Rightful Place: Race Recognition and a More Complete Commonwealth, Melbourne: Quarterly Essay, 2014.

40 Don Watson, Caledonia Australis: Scottish Highlanders on the Frontier of Australia (Sydney: Collins, 1984), pp.165-70. The first settlers of Winnipeg were brought from Scotland for the same reason in 1812. There is a bronze group along the riverbank and the story is told on the St Andrew's Society website. After some 'bloodshed and open conflict' 200 settlers and 100 'soldier farmers' were established by 1821 . The statues were unveiled in 2008. See also Ann Curthoys, 'Scottish Settlers and Indigenous People in Colonial Australia', in For Auld Lang Syne: Images of Scottish Australia from First Fleet to Federation, ed. Alison Inglis and Patricia Tryon Macdonald (Ballarat: Art Gallery of Ballarat, 2014), 83-100.

41 Don Watson, The Bush: Travels in the Heart of Australia (Melbourne: Penguin, 2014). There are unmistakeable references to genocidal actions and attitudes on 72-89, 132-9, 158-162 271-8, 316-329, 343-353 and elsewhere.

42 The British historian Tom Lawson has made an important advance in promoting the responsibility of the colonial power. Tom Lawson, The Last Man: A British Genocide in Tasmania (London: I.B. Taurus, 2014). See also John Docker (2015) 'A plethora of intentions: genocide, settler colonialism and historical consciousness in Australia and Britain', The International Journal of Human Rights, 19:1, 74-89.

43 Prime Minister Paul Keating, launching the 1993 International Year of Indigenous Peoples, at Redfern, Sydney, on 10 December 1992. http://www.youtube.com/watch?v=mKhmTLN3Ddo

Keating went on to attempt a fair resolution to the Mabo decision on continuity of Indigenous land ownership, and to initiate the National Inquiry into the Stolen Generations. See also Donna-Lee Freize "Simply Bred Out": Genocide and the Ethical in the Stolen Generations' in Alexander Laban Hinton, Thomas La Pointe, and Douglas Irvin Erickson eds Hidden Genocides: Power, Knowledge, Memory (New Brunswick, NJ: Rutgers University Press, 2013), 83-95.

44 See Wikipedia, 'History wars'. The sensitivity about the word genocide is visible in the widely read Aboriginal Australians by Richard Broome (Sydney: Allen \& Unwin, 1982). After the settlement of Melbourne in 1835, he writes, Indigenous numbers dropped from more than 10,000 to less than 2,000 in eighteen years - a decline over 80 percent. The 'fully revised' fourth edition published in 2010 repeats the figures. There is a more extensive discussion of the causes, primarily disease, poor diet, disruption and despair. None of these factors, not even the killings or the tragically low birth rate, are considered as genocide, and there is no indication in the notes or bibliography of the extensive writing on Australian genocide since the first edition.

45 Stanner 'The Dreaming' (1953) in The Dreaming and Other Essays, (Melbourne: Black inc, 2009) 55-72. 'Him got other way', 57. For a current example, see the opposition of the Wangan and Jagalingou people to the Queensland Government or Adani for the development of one of the word's biggest coal mines. And on the ever more urgent problems of water allocation, http://www.motherjones.com/tom-philpott/2014/04/ california-drought-groundwater-drilling

Stanner is very careful about genocide, the more so because his original field work was in the 1930s. But he makes clear in influential essays (notably 'Durugam: a Nangiomeri' in this collection, esp. 30-35) that the loss of whole tribal groups with distinctive languages and cultures, with hundreds of individuals lost to disease, drink and other causes, was a disaster in the encounter with a colonial world, even as Aborigines adapted to it. 
46 'I have heard that you want to settle us on a reservation near the mountains. I don't want to settle. I want to roam over the prairies. There I feel free and happy, but when we settle down we grow pale and die... These soldiers cut down my timber; they kill my buffalo; and when I see that, my heart feels like bursting... Has the white man become a child that he should recklessly kill and not eat? When the red men slay game, they do so that they may live and not starve.' Satanta, Chief of the Kiowas, 1874. Dee Brown, Bury My Heart at Wounded Knee (1970) Illustrated edition. (New York: Sterling, 2009), 2. As I was contemplating this, my 11 year-old grand-daughter Chloe was writing her own essay on human destruction of animal habitat. 'How would you feel if someone cut down your home?'

47 Zimmerer warns climate change 'also has serious consequences for the perpetrator-victim positions. No longer would scholars and genocide prevention activists from the global north be - by virtue of their location alone - the "good guys" and the perpetrators always in the global south, but light would be shed on the very uncomfortable fact that genocide scholars and others are perpetrators as well.' Jürgen Zimmerer, 'Climate change, environmental violence and genocide', The International Journal of Human Rights 18: 3 (2014): 265-280, following up his 2011 warning about anthropogenic genocide on an unimagined scale: 'Genocide studies for the twenty-first century: a departing editor's perspective', Journal of Genocide Research 13, 3 (2011): 205-208. See also Mark Levene and Daniele Conversi, Subsistence societies, globalisation, climate change and genocide: discourse of vulnerability and resilience', The International Journal of Human Rights, 18, 3 (2014): 281-297; and Martin Crook \& Damien Short, 'Marx, Lemkin and the genocide-ecocide nexus' The International Journal of Human Rights, 18, 3 (2014): 298-319. These essays have now been published as a book, Climate Change and Genocide: Environmental Violence in the 21 $1^{\text {st }}$ Century (Abington: Routledge, 2015).

48 I owe the phrase 'reductive legal concept' to Andrew Woolford. See E. A. Christodoulidis, '"Truth and Reconciliation" as Risks', Social \& Legal Studies, 9, 2, (2000): 179-204, and Woolford, 'The Limits of Justice: Certainty, Affirmative Repair, and Aboriginality', Journal of Human Rights, 3, 4 (2004). 